\title{
NITRATE AND NITRITE IN DRINKING WATER AFFECT ANTIOXIDANT ENZYMES IN ERYTHROCYTES OF RATS
}

\author{
E. SIERRA-CAMPOS ${ }^{1 凶}$, M. A. VALDEZ-SOLANA ${ }^{1}$, M. I. CAMPOS-ALMAZÁN ${ }^{1}$, \\ C. AVITIA-DOMÍNGUEZ ${ }^{2}$, J. L. HERNÁNDEZ-RIVERA ${ }^{1}$, J. A. DE LIRA-SÁNCHEZ1, \\ G. GARCIA-ARENAS ${ }^{3}$, A. TÉLLEZ-VALENCIA ${ }^{2}$
}

\author{
${ }^{1}$ Faculty of Chemical Sciences, Campus Gómez Palacio, University Juarez \\ of Durango State, Gomez Palacio, Durango, Mexico; \\ e-mail: ericksier@gmail.com; \\ ${ }^{2}$ Faculty of Medicine and Nutrition, Campus Durango, \\ University Juarez of Durango State, Durango, Mexico; \\ ${ }^{3}$ Faculty of Health Sciences, Campus Gómez Palacio, University Juarez \\ of Durango State, Gomez Palacio, Durango, Mexico
}

The present study evaluated the effect of short term intake of nitrite and nitrate drinking water on the antioxidant system and membrane damage of rat erythrocytes. Wistar rats, were randomly divided into three groups as follows; the group I received only distilled water ad libitum; the group II was given water with Nitrate (a dose of $124 \mathrm{mg} / \mathrm{kg}$ of nitrate-nitrogen) as drinking water and the group III was given nitrites dissolved in distilled water in a dose of $150 \mathrm{mg} / \mathrm{kg}$ for 7 days. At the end of the study, group III rats showed a significant decrease in activities of glutathione peroxidase (GPX), glucose 6-phosphate dehydrogenase (G6P$D H$ ) and catalase (CAT), while in group II rats, the activity of GPx and CAT were significantly reduced, but no significant changes in glutathione reductase activity and peroxynitrite levels were observed. On the other hand, malondialdehyde (MDA) was increased in both groups with respect to group I. Also, our major results indicate that all treatments changed methemoglobin levels and osmotic fragility in comparison to group I rats. The intensity of alterations was found more severe in rats of group III, followed by rats of group II. It can be concluded from these observations that nitrate or nitrite leads to alterations in the erythrocytes antioxidant defense status mainly throughout NADPH relate enzymes.

Ke ywords: nitrate, nitrite, oxidative stress, antioxidant enzymes, methemoglobin, erythrocytes.

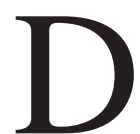

rinking water is derived from two basic sources: surface waters, such as rivers and reservoirs, and groundwater. All water contains natural contaminants, particularly inorganic compounds that arise from the geological strata through which water flows and, to a varying extent, anthropogenic pollution by both microorganisms and chemicals. The quality of drinking water and possible associated health risks vary throughout the world were some regions show high levels of arsenic and fluoride, or contamination by pathogens [1]. There is a number of possible sources of man-made contaminants, some of which are more important than others. Agriculture is another source of chemical contamination. In this case, the most important contaminant is nitrate, which can cause methemoglobinaemia, or blue-baby syndrome, in bottle-fed infants under 3 months of age [2].

Comarca Lagunera Region of Mexico is famed as the largest milk-producing area. The Laguna faces a serious problem of over-exploitation and contamination of its water sources. Located in a semidesert, it produces cotton, alfalfa, walnut, cattle and goats. Such economic activities, along with the large production of milk and beer, consume the aquifer reserves in the region. As a result, the remaining water supplies are contaminated with arsenic, nitrates and other contaminants [3], an important factor for health problems in hundreds of people in the local communities.

(C) 2018 Sierra-Campos E. et al. This is an open-access article distributed under the terms of the Creative Commons Attribution License, which permits unrestricted use, distribution, and reproduction in any medium, provided the original author and source are credited. 
The intoxication with nitrates is produced by exposure levels of $450 \mathrm{mg} / 1$ through drinking water. Nitrate itself is non-toxic, but in the gastrointestinal tract, a percentage of nitrates are reduced to nitrites, which are ten times more toxic than nitrate due to its oxidative properties. Nitrites are then absorbed into the bloodstream, from where they can reach other tissues. The main mechanism of nitrite toxicity is the oxidation of the $\mathrm{Fe}^{2+}$ to $\mathrm{Fe}^{3+}$, converting the hemoglobin into methemoglobin (MetHb).

Several in vivo and in vitro studies reported that nitrites and nitrates could induce oxidative damage through the release of free radicals associated with a decrease in glutathione (GSH) level in the intracellular medium associated with membrane lipid peroxidation $[4,5]$.

The erythrocytes are highly susceptible to oxidative damage due to its high levels of oxygen and hemoglobin, a powerful promoter of the oxidative process [6]. Although their primary function is to transport the respiratory gases, oxygen and carbon dioxide, between the lungs and tissues, these circulatory cells are equipped with effective antioxidative systems that make them mobile free radical scavengers, providing antioxidant protection not only to themselves but also to other tissues and organs in the body. This protective system includes superoxide dismutase (SOD), catalase (CAT), glutathione (GSH) and glutathione peroxidase (GPx) [7].

As an oxygen shuttle, the erythrocytes must continue to perform this essential task while being exposed to a wide range of environments for each vascular circuit and to a variety of xenobiotics across its lifetime. Accordingly, several studies have been dedicated to understanding the relationship between antioxidant system of erythrocytes and diverses pathophysiological conditions as senescence and diabetes $[8,9]$.

A review of latest research findings on nitrate toxicology over erythrocytes has produced conflicting results that do not appear to be relevant on adult human exposure. However, it has been reported that nitrite added to erythrocytes oxidizes glutathione and causes membrane damage, protein oxidation, high levels of lipid peroxidation [10] and also perturbs energy metabolism in these cells [11]. Besides, the administration of nitrite to mice leads to an increase in the metHb level, the activity of GR and glucose 6-phosphate dehydrogenase (G6PDH) of erythrocytes, as well as a decrease in the activity of SOD and CAT. A high level of erythrocyte lipid per- oxidation after nitrite intoxication is observed [12]. Moreover, Bouaziz-Ketata et al., [13] found that the nitrate-treated group showed a marked reduction in the antioxidant enzyme activities, along with an elevation on lipid peroxidation levels, a reduction in the total GSH content in erythrocytes and a significant increase in the frequencies of total chromosomal aberrations and micronucleus in bone-marrow cells. As the toxicity of nitrate results from its conversion to nitrite and the possible endogenous formation of reactive nitrogen species (RNS) which cell damage. However, there are studies that suggested nitrite rapidly enters erythrocytes and reacts with oxyhemoglobin but does not exert a strong oxidant stress on these cells $[14,15]$.

In addition to detrimental effects, a metabolic requirement for nitrite has been proposed. Nitrite has emerged as an endogenous signaling molecule with potential therapeutic implications for cardiovascular diseases. It is now clear that nitrite can act as an antioxidant and a promising therapeutic agent to protect against myocardial ischemia-reperfusion injury through mediating nitric oxide (NO') homeostasis [16]. It has been found that plasma nitrite concentrations reflect the degree of endothelial dysfunction in humans [17].

Previously, Lu et al., [18] reported that nitrites possess anti-and pro-oxidant activities by interfering hemoglobin-dependent redox reactions. Therefore, the dual effects on hemoglobin-triggered oxidative stress may provide new insights into the physiological and toxicological implications of nitrite with hemoproteins. Thus, it is difficult to determine whether oxidative stress is caused by nitrate or by the role of antioxidant defense system's response to nitrate toxicity. Despite of abundant literature data, much still remains unexplained.

Therefore, we set out to examine in detail the effects of nitrates and nitrites on the erythrocytes and to determine whether the putative NRS or ROS release of the compounds present in drinking water provides greater oxidative stress on erythrocytes of rats.

\section{Materials and Methods}

This study was approved by the Local Ethics Committee for Animal Experiments at Faculty of Chemical Sciences, University Juarez of Durango State (Mexico). Procedures involving the animals and their care were according to the institutional guidelines, in compliance with national and inter- 
national laws and criteria for the use of animals in Biomedical research was followed (19).

Experimental design. The female Wistar rats were housed in well-ventilated polypropylene cages under controlled temperature $\left(25^{\circ} \mathrm{C}\right)$, relative humidity (60-80\%), and light/dark cycle of $12 \mathrm{~h}$. They were provided with animal feed (Harland, USA) and water ad libitum.

Estimation of the dose range and percentage of mortalities. The nitrite was administered to rats by oral route (per os), in an increasing and single dose, in order to determine the lethal dose $50 \%\left(\mathrm{LD}_{50}\right)$. The rats were separated in groups of 5 animals. The nitrite was administrated p.o at doses of $0,100,200$, 400 and $500 \mathrm{mg} / 1$ [equivalent to $0,2,4,8,10 \mathrm{mg}$ nitrite-nitrogen $/ \mathrm{kg}$ of body weight (bw)]. The signs of toxicity and death were observed up to $48 \mathrm{~h}$ after the treatment. The $\mathrm{LD}_{50}$ was calculated by means of the method of Miller and Tainter, [20]. The $\mathrm{LD}_{50}$ value for acute toxicity of sodium nitrite obtained was $232.31 \mathrm{mg} / \mathrm{kg}$ (equivalent to $4.64 \mathrm{mg}$ nitritenitrogen $/ \mathrm{kg}$ bw). We have not determined $\mathrm{LD}_{50}$ for nitrate due that literature reported in short-term and long-term toxicity experiments in rats dose levels ranged from 366 to $1825 \mathrm{mg}$ nitrate-nitrogen $/ \mathrm{kg} \mathrm{bw} /$ day [21].

The dose of $150 \mathrm{mg} / \mathrm{l}$ of nitrite was selected after performing preliminary assays of increasing doses that alter methemoglobin levels, osmotic fragility, and antioxidant enzyme activities. The dose of $124 \mathrm{mg} / 1$ of nitrate was chosen because it exceeds maximum permissible limit of $10 \mathrm{mg} / 1$ [22].

Experimental design. The animals were randomly divided into three groups, each comprising seven animals and orally administered the respective doses of $150 \mathrm{mg} / \mathrm{kg}$ potassium nitrite and $124 \mathrm{mg} / \mathrm{kg}$ potassium nitrate and distilled water by intragastric gavage daily for a period of 7 days as shown below.

Group I (untreated control); animals were given distilled water ( 0.3 to $0.7 \mathrm{mg} / \mathrm{kg}$ bw/day, equivalent to $>0.03 \mathrm{mg}$ Nitrate-nitrogen $/ \mathrm{kg}$ bw/day).

Group II (nitrate); animals administered with $124 \mathrm{mg} / \mathrm{kg}$ bw/day, equivalent to $4.6 \mathrm{mg}$ nitrate-nitrogen/kg bw/day.

Group III (nitrite); animals administered nitrite (150 mg/kg bw/day, equivalent to average daily doses of approximately $3.5 \mathrm{mg}$ nitrite-nitrogen $/ \mathrm{kg}$ bw/day).

Isolation of rat erythrocytes. Blood samples were obtained by cardiac puncture under sodium pentobarbital anesthesia and were collected into a tube containing EDTA. Then centrifuged at $800 \mathrm{~g}$ at $4{ }^{\circ} \mathrm{C}$ for $10 \mathrm{~min}$. The plasma and buffy coat were removed by aspiration and discarded. The erythrocytes were washed three times in buffer containing $21.0 \mathrm{mM}$ Tris, $\mathrm{pH}$ 7.4. Cells were prepared on the day of use and diluted to $10 \%$ hematocrit with PBS $(0.9 \% \mathrm{NaCl}$ in $0.01 \mathrm{M}$ phosphate buffer, $\mathrm{pH} 7.4)$ containing $100 \mathrm{mM}$ EDTA [23].

Measurement of free hemoglobin and methemoglobin. Samples were centrifuged at $800 \mathrm{~g}$ at $4{ }^{\circ} \mathrm{C}$ for $10 \mathrm{~min}$, and the presence of free hemoglobin in the supernatant was determined by light absorption at $405 \mathrm{~nm}$ [24]. Methemoglobin and oxyhemoglobin were measured by spectrophotometry method (HACH DR5000, UV/VIS, Mexico) using 630 and $540 \mathrm{~nm}$, respectively [25].

Hemolysis. Hemolysis was determined by measuring released hemoglobin into the supernatant of the induced samples at $540 \mathrm{~nm}$ and was represented on the basis of the maximum absorbance $(100 \%)$ in the aliquots of erythrocytes completely hemolysed in distilled water [26].

Osmotic fragility. The procedure was a slightly modified method of O'Dell et al., [27]. A $100 \mu 1$ aliquot of washed erythrocytes suspension was added to tubes containing $0.3 \%, 0.4 \%$ and $0.9 \%$ buffered salt solution (PBS, $\mathrm{pH}$ 7.4). These tubes were allowed to stand at room temperature for $30 \mathrm{~min}$, centrifuged at $800 \mathrm{~g}$ to pellet the cells and the absorbance of the supernatant was measured at $540 \mathrm{~nm}$. PBS $(0.9 \%)$ was considered as a control sample.

Peroxynitrite assay. Peroxynitrite was assayed by diluting aliquots of blood samples into $1.0 \mathrm{M}$ $\mathrm{NaOH}$ and measuring the increase in absorbance at $302 \mathrm{~nm}$. As a control, samples were added to $100 \mathrm{mM}$ potassium phosphate (pH 7.4). The decrease in absorbance was measured at neutral $\mathrm{pH}$ as peroxynitrite decomposes [28].

Evaluation of enzymatic activities. CAT activity was measured in hemolysates according to Aebi, [29]. Decomposition of $\mathrm{H}_{2} \mathrm{O}_{2}$ was followed directly by monitoring the decrease of absorbance at $240 \mathrm{~nm}$. The activity of glutathione reductase (GR) was determined by a method of Staal et al., [30]. The rate of oxidation of NADPH was immediately monitored at $340 \mathrm{~nm}$ for $5 \mathrm{~min}$ at $15 \mathrm{~s}$ intervals. The activity of GR was calculated using the molar extinction coefficient of $6.22 \mathrm{M}^{-1} \mathrm{~cm}^{-1}$. G6PDH activity was measured by the modified method of Zinkham, [31] by observing the conversion of $\mathrm{NADP}^{+}$into NADPH after addition of glucose 6-phosphate. GPx activity was determined by the coupled assay of Paglia and Valentine [32] using t-butyl hydroperoxide as substrate. Lactate dehydrogenase (LDH) activity was 
usually measured according to Bergmeyer, [33]. The production for $\mathrm{NAD}^{+}$was followed by a decrease in absorbance at $340 \mathrm{~nm}$. The molar extinction coefficient for NAD(P)H was $6.22 \mathrm{M}^{-1} \mathrm{~cm}^{-1}$ at $340 \mathrm{~nm}$ and used to calculate the enzyme activity.

Preparation of erythrocyte ghost membranes. Packed erythrocytes were obtained by centrifugation of whole rat blood at $800 \mathrm{~g}$ for $10 \mathrm{~min}$ at $4{ }^{\circ} \mathrm{C}$. After the removal of the plasma and the buffy coat by aspiration, cells were washed three times with $0.9 \%$ $\mathrm{NaCl}$ solution. For the preparation of hemoglobinfree ghosts, a method slightly modified from that of Dodge et al., [34] was used. Hemolysis of the washed erythrocytes was performed in $5 \mathrm{mM}$ sodium phosphate buffer $(\mathrm{pH} \mathrm{8.0)}$ and the pellet was obtained by centrifugation at $7,500 \mathrm{~g}$ for $30 \mathrm{~min}$ at $4{ }^{\circ} \mathrm{C}$. This process was repeated five to seven times until the pellet became colorless. The ghosts were finally suspended in the same buffer at a concentration of about $2 \mathrm{mg}$ of protein $/ \mathrm{ml}$ and stored at $-20^{\circ} \mathrm{C}$. Membrane protein was estimated by the procedure of Lowry et al. [35].

Lipid peroxidation (LPO). Lipid peroxidation was assessed by measurement of thiobarbituric acid reactive substances (TBARS) after the addition of $2 \mathrm{ml}$ of TBA-TCA-HCl reagent as described by Buege and Aust, [36], and placed in a boiling water bath for $60 \mathrm{~min}$. The samples were cooled and centrifuged at 7,500 $\mathrm{g}$ for $30 \mathrm{~min}$ at $4{ }^{\circ} \mathrm{C}$. The absorbance of the simple (the pink colored product formed when malondialdehyde reacts with TBA) was recorded at $535 \mathrm{~nm}$ against the appropriate blank. The malondialdehyde concentration of the samples was calculated using an extinction coefficient of $1.56 \times 10^{5} \mathrm{M}^{-1} \mathrm{~cm}^{-1}$.

Statistical analyses. The results were represented as mean \pm SD. Statistics were applied using SigmaPlot v11. 0 (Systat Software Inc). Values between the groups were analyzed by one-way ANOVA followed by Pearson's multiple comparison tests to determine the statistical significance between various groups. Differences were considered to be statistically significant levels $P<0.05$.

\section{Results and Discussion}

Blood, as an internal transport, is an important tool to assess the toxicant of organisms and one of the major routes of absorption of environmental pollutions [37]. Nitrates consumed in food are concentrated in the saliva and converted to nitrite by commensal in the mouth [38]. Nitrates and nitrites may be toxics at serum concentrations barely exceeding the therapeutic level of $3 \mathrm{mg} / \mathrm{kg}$ [39]. Concentrations about or above $10 \mathrm{mg} / \mathrm{l}$ for nitrates and $1 \mathrm{mg} / \mathrm{l}$ for nitrites are considered to be extremely toxic or even fatal [40]. The dose given to group II and group III in this study is with the toxic range.

The effect of treatment with nitrate (group II) and nitrite (group III) on methemoglobin, MDA, peroxynitrite and lactate dehydrogenase is shown in Table 1. Significant differences were seen between the MetHb, MDA, peroxynitrite and LDH activity values of group I and both treated-groups (II and III). Table 1 shows that the level of MDA was increased and LDH activity was decreased. The MDA concentration was higher in group II compared to group I and III. There was no difference in peroxynitrite levels between group I and group II, but it was significantly higher in group III. Compared to the group I (1.7\%), the MetHb levels of group II and group III were significantly higher (5 and $13.9 \%$, respectively).

Erythrocytes osmotic fragility, the sensitivity to changes in osmotic pressure characteristic of erythrocytes, has been found to be altered in various pathological conditions. The integrity of erythrocytes may be determined by measuring the erythrocytes osmotic fragility changes [41]. Fragility is measured by the degree of hemolysis in hypotonic $\mathrm{NaCl}$ solution. The hemolysis was significantly increased in the groups II and III in the present study. In addition, fragility can be used as an indicator of oxidative stress and the measure of defense against free radicals in animals [42, 43].

In group I, the osmotic fragility levels were found to be maximum at $0.35 \% \mathrm{NaCl}$ and minimum at $0.55 \% \mathrm{NaCl}$, whereas in group II reached a maximum at $0.4 \% \mathrm{NaCl}$ and minimum at $0.65 \% \mathrm{NaCl}$ and in group III reached a maximum at $0.4 \% \mathrm{NaCl}$ and minimum at $0.6 \% \mathrm{NaCl}$. These values represent a significant increase of the maximum osmotic fragility limits between group I and both treated-groups (II and III) $(P<0.05)$. Hemolysis in groups II and III was higher than that of group I. The standard hemolytic increment curve of both groups was shifted to the right when compared to the curve for the group I (Fig. 1). The concentration of $\mathrm{NaCl}$ at which $50 \%$ of erythrocytes were lysed was considered the median osmotic fragility (MOF). The results showed that MOF was significantly greater in group II than in group I $(0.6 \pm 0.03 \%$ vs $0.41 \pm 0.01 \%)$. Percentage erythrocyte fragility was highest in the group II compared to group III $(0.6 \pm 0.03 \%$ vs $0.52 \pm 0.05 \%)$. 
Ta b le 1. Erythrocyte oxidative damage biomarkers by nitrate water consumption and nitrite drinking water

\begin{tabular}{c|c|c|c|c}
\hline Group & MetHb, \% & LDH, $\mu$ mol $/ \mathrm{min} / \mu \mathrm{g}$ protein & $\begin{array}{c}\text { Peroxynitrite, } \mathrm{nmol} / \mathrm{mg} \\
\text { protein }\end{array}$ & MDA, $\mu \mathrm{mol} / 1$ \\
\hline I & $1.70 \pm 0.02$ & $20.88 \pm 1.8$ & $1.9 \pm 0.2$ & $2.02 \pm 0.22$ \\
II & $4.95 \pm 0.35^{\mathrm{a}}$ & $23.10 \pm 1.0^{\mathrm{a}}$ & $2.3 \pm 1.0$ & $4.86 \pm 0.41^{\mathrm{a}}$ \\
III & $13.97 \pm 0.46^{\mathrm{ab}}$ & $19.70 \pm 1.6^{\mathrm{b}}$ & $3.5 \pm 0.4^{\mathrm{a}}$ & $2.72 \pm 0.23^{\mathrm{ab}}$ \\
\hline
\end{tabular}

$\overline{\mathrm{MetHb}}$ - Methemoglobin; LDH - Lactate dehydrogenase; MDA - Malondialdehyde. Significant differences were obtained by Duncan's multiple comparison tests. Data are expressed as mean $\pm \mathrm{SD},(n=7)$. ${ }^{\text {Significant difference from }}$

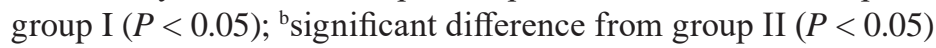

These findings are in agreement with previous reports [11].

Oxygen radicals are produced continuously in erythrocytes by hemoglobin autooxidation [44], and this process is accelerated upon exposure to a large number of xenobiotic agents $[45,46]$. Thus, oxyHb autooxidation is probably the main source of $\mathrm{H}_{2} \mathrm{O}_{2}$ in red blood cell [47]. Moreover, the free hemoglobin exposed to $\mathrm{H}_{2} \mathrm{O}_{2}$ causes heme degradation with the release of iron ions which are catalytically active in initiating free radicals and lipid peroxidation and this leads to membrane damage and eventually hemolysis [48].

Results of treatment of nitrate and nitrites on redox system are presented in Table 2. An increase in the activity of CAT and SOD is usually observed in the face of environmental pollutants [49] since SOD-CAT system represents the first line of defense against oxidative stress. CAT activity is useful as an indicator of the inhibition by ROS. In the present study resulted in a significant decrease in the erythrocytes CAT activity was found in group II. While that the group III was resulted in approximately $20 \%$ decrease in CAT activity (Table 2). The decrease was found to be statistically significant $(P<0.05)$. The decreased CAT activity may be due to superoxide accumulation, which has been shown to inhibit CAT activity [50].

On the other hand, GPx and GR are both intracellular GSH-related enzymes, working with GSH in participation in the process of oxidative stress injury. Our results showed that GPx activity in group II rats was comparable to group I (Table 2). In the case of GPx 50\% decrease was observed in the enzyme activity in group III and insignificant change (about $5 \%$ ) was observed in the group II. Table 2 shows the activity of GR in erythrocytes of different groups. No significant changes were observed in group II and III rats versus group I. In addition, treatedgroups was resulted in decreased activity of G6PDH.
A decrease ranging from 30 to $90 \%$ in the enzyme activity was observed in case of group II and III. These data greatly supports and confirms that both nitrate and nitrite induce oxidative damage in rat erythrocytes. In accordance with this, recent studies $[11,51]$ has reported a decrease in the levels of these enzymes in human erythrocytes treated with nitrite. In addition, it was observed that nitrite increased the activities of acid phosphatase, AMP deaminase, and LDH.

Hence osmotic fragility is a measure of the resistance of erythrocytes to burst under hypotonic conditions. The ability of normal erythrocytes to withstand hypotonicity results from its biconcave disk shape, which allows the erythrocyte to increase its volume by $70 \%$ before membrane rupture [52]. Lower osmotic fragility limits have been reported in various diseases as a result of increased lipoper-

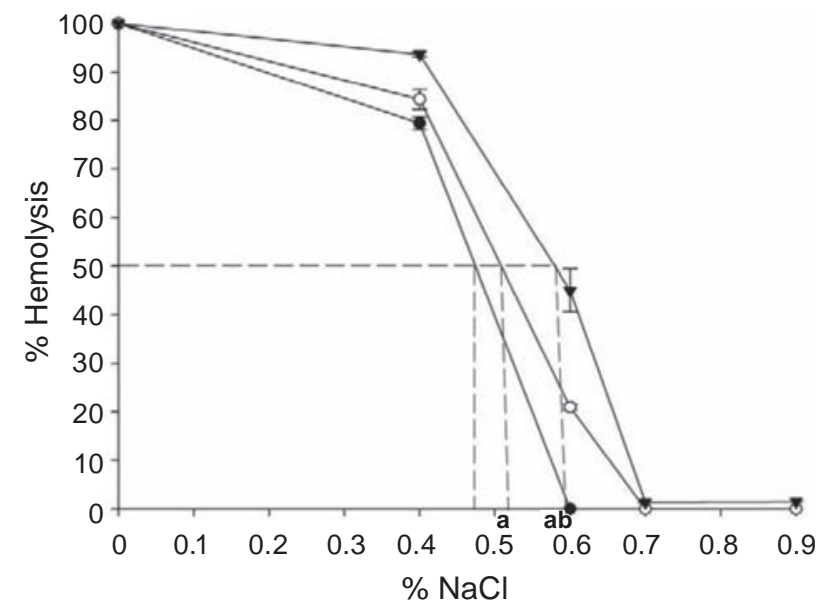

Fig. 1. Osmotic resistance curves of different groups of rats. The results shown are representative of three independent experiments. Group I (black circles); Group II (inverted black triangle); Group III (white circles). ${ }^{a}$ Significant difference from group I $(P<0.05)$; ${ }^{b}$ significant difference from group III $(P<0.05)$ 
oxidation [53]. After nitrate or nitrite was administrated, both groups II and III showed right-shifted sigmoidal osmotic fragility curves (Fig. 1), indicating an increase of the osmotic fragility and possibly a membrane damage.

According to Krishnamoorthy and Sangeetha, [54], sodium nitrite (300 $\mathrm{mg} / \mathrm{kg}$ body weight) significantly increased the lipoperoxidation and the activities of liver marker enzymes such as alanine aminotransferase, aspartate aminotransferase, acid phosphatase and lactate dehydrogenase, and decreased the activities of antioxidant enzymes such as SOD, CAT, and reduced GSH level.

The G6PDH is an important enzyme of hexose monophosphate shunt and its function in the mature erythrocytes is to generate NADPH, which is required for the conversion of oxidized glutathione (GSSG) to GSH that in turn is necessary for membrane integrity of erythrocyte membranes [55].

It is well documented in the literature that in vivo administration of various xenobiotics results in a decrease in GSH content of erythrocytes [56]. Reduction in enzyme activities with higher doses of contaminants may be related to consumption of enzyme against oxidative stress. The increased lipoperoxidation in group II could be attributed to the nature of antioxidant synergistic functioning, which may partly explain the mechanism of their reduced activity. Inhibition of G6PDH leads to accumulation of the GSSG by preventing reduction to GSH, suggesting that the consumption of GSH might not have been compensated by GR. Thus, reduced supply of NADPH could be a cause for GPx activity; when CAT or GPx fails to eliminate hydrogen peroxide from the cell. Thus, erythrocytes with decreased GSH content had a shorter lifetime and increased susceptibility to hemolysis (Fig. 2, A). This indicates accumulation of $\mathrm{H}_{2} \mathrm{O}_{2}$ in erythrocytes. Therefore, the oxidative stress caused by nitrates may be mediated by the conversion of accumulated $\mathrm{H}_{2} \mathrm{O}_{2}$ to hydroxyl radical $\left(\mathrm{OH}^{*}\right)$. The $\mathrm{OH}^{*}$ oxidizes polyunsaturated fatty acids in plasma membranes inducing the formation of lipid peroxides (Fig. 2, A). Our results support the idea that erythrocyte hemolysis is enhanced as a result of increased lipid peroxidation. Therefore, it could be inferred that nitrate administration results in an increased lipid peroxidation and increased MDA levels, playing a causal role in increasing the osmotic fragility of the erythrocytes (dotted line, Fig. 2, A).

During past decade, investigations have focused on the beneficial effects of nitrate, reporting that administration of nitrate has strong NOlike outcomes in both animals and humans [57]. Inorganic nitrite and nitrate are no longer considered inert end products of $\mathrm{NO}^{*}$ metabolism but have been shown to be biologically active in the vasculature. Nitrite has been shown to have vasoprotective and anti-inflammatory properties [58, 59]. However, these potentially therapeutic properties of nitrite and nitrate have largely been attributed to the ability of inorganic nitrite and nitrate to function as a reservoir for further NO` production. Nitrate is reduced to nitrite, mostly by bacterial nitrate reductase, and then nitrite is converted back to NO through a variety of enzymatic and nonenzymatic mechanisms, both in the circulation and in the tissues [60].

The effect of $\mathrm{NO}^{*}$ on cells ultimately depends on many complex conditions such as the rate of $\mathrm{NO}^{*}$ production and its rate of diffusion, the concentration of potential reactants such as superoxide $\left(\mathrm{O}_{2}{ }^{-}\right)$ and oxygen, the levels of antioxidants and the distances between generator cells and target cells [61]. Thus, NO has both beneficial and harmful effects,

Table 2. Erythrocyte oxidative stress-defense systems affected by nitrate water consumption and nitrite drinking water

\begin{tabular}{c|c|c|c|c}
\hline Group & $\begin{array}{c}\text { CAT, } \\
\mathrm{mmol} / \mathrm{min} / \mu \mathrm{g} \text { protein }\end{array}$ & $\begin{array}{c}\mathrm{GPx}, \\
\mu \mathrm{mol} / \mathrm{min} / \mu \mathrm{g} \text { protein }\end{array}$ & $\begin{array}{c}\mathrm{GR}, \\
\mu \mathrm{mol} / \mathrm{min} / \mu \mathrm{g} \text { protein }\end{array}$ & $\begin{array}{c}\mathrm{G} 6 \mathrm{PDH}, \\
\mu \mathrm{mol} / \mathrm{min} / \mu \mathrm{g} \text { protein }\end{array}$ \\
\hline I & $16.53 \pm 2.9$ & $4.93 \pm 0.49$ & $0.113 \pm 0.01$ & $52.3 \pm 1.2$ \\
II & $5.63 \pm 1.4^{\mathrm{a}}$ & $5.18 \pm 0.52$ & $0.161 \pm 0.09$ & $37.6 \pm 4.7^{\mathrm{a}}$ \\
III & $13.27 \pm 0.05^{\mathrm{ab}}$ & $2.61 \pm 0.27^{\mathrm{ab}}$ & $0.102 \pm 0.02$ & $6.11 \pm 0.28^{\mathrm{ab}}$ \\
\hline
\end{tabular}

CAT - Catalase; GPx - Glutathione peroxidase; GR - Glutathione reductase; G6PDH - Glucose-6-phosphate dehydrogenase. Significant differences were obtained by Duncan's multiple comparison tests. Data are expressed as mean \pm SD, $(n=7)$. a Significant difference from control $(P<0.05)$. ${ }^{b}$ Significant difference from group II $(P<0.05)$ 


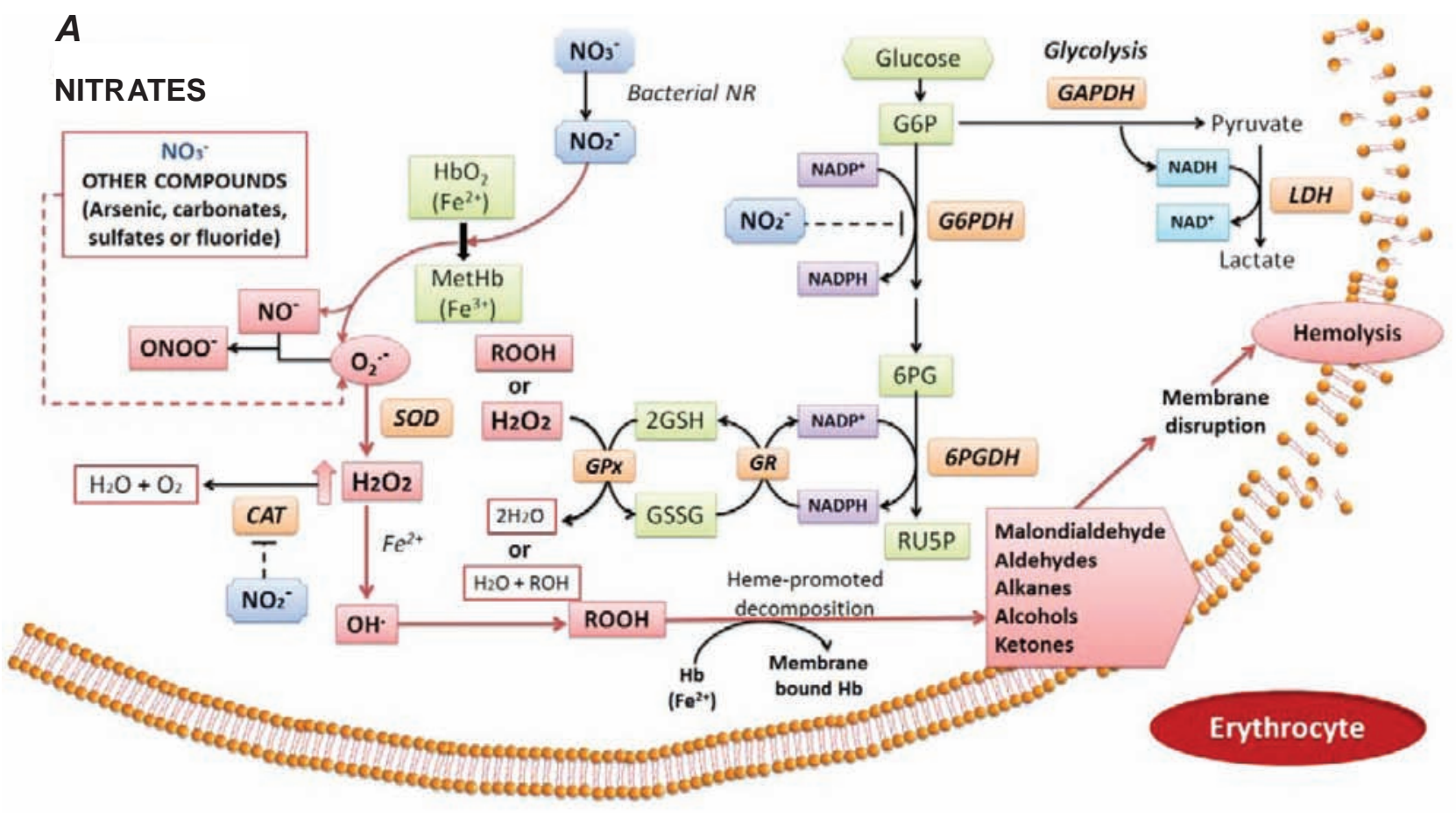

\section{B}

\section{NITRITES}

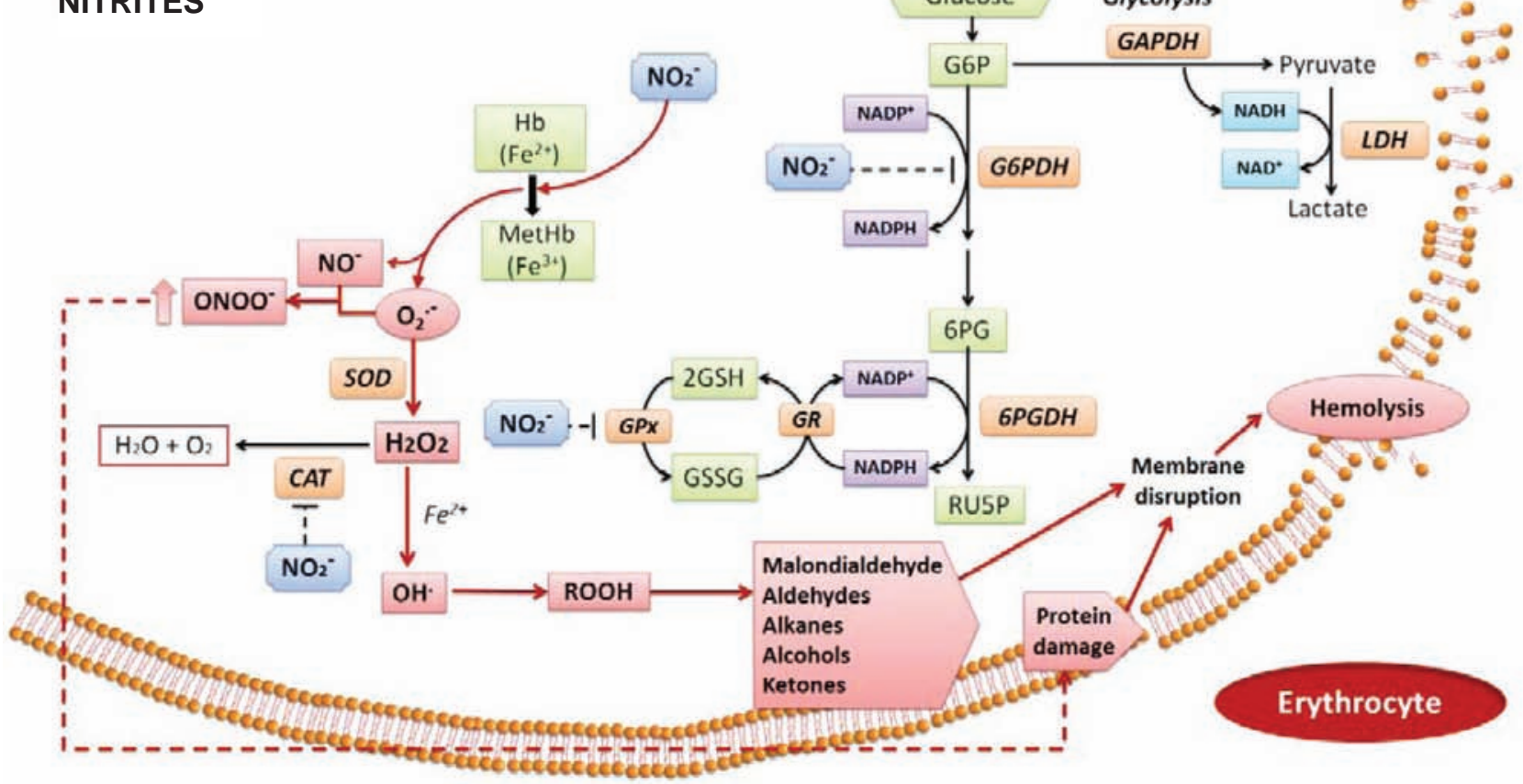

Fig. 2. Scheme of the postulated mechanism of nitrate and nitrite-induced hemoglobin oxidation, lipid peroxidation, and hemolysis. A) Nitrates and $\mathbf{B}$ ) Nitrites can be exerting cellular stress and cause hemolysis via increased ROS or RNS production and oxidative stress. GAPDH, glyceraldehide-3P dehydrogenase; G6PDH, glucose-6P dehydrogenase; SOD, superoxide dismutase; $C A T$, catalase, $N R$, nitrate reductase; $R O O H$, hydroperoxides; GSH, reduced glutathione; GSSG, oxidized glutathione; $\mathrm{NO}_{2}^{-}$, nitrite; $\mathrm{Hb}$, hemoglobin, MetHb, methemoglobin 
depending on its concentration. At low concentrations, it is a chemical messenger that directly integrates and differentiates time-dependent responses to stress and defense against pathogens [62]. At high levels, and in the presence of ROS, NO produces reactive nitrogen species (RNS) that create oxidative and nitrosative stresses [63].

In the case of nitrite stress, the formation of RNS is not an inescapable consequence of synthesizing NO* The NO* is efficiently removed by reacting with oxyhemoglobin to form nitrate, which prevents even the highest rates of NO• synthesis from directly reacting with oxygen to form significant amounts of nitrogen dioxide $\left(\mathrm{NO}_{2}{ }^{\circ}\right)$. However, the simultaneous activation of $\mathrm{O}_{2}^{-}$- synthesis along with $\mathrm{NO}^{-}$will completely transform the biological actions of $\mathrm{NO}^{\circ}$ by forming peroxynitrite ( $\left.\mathrm{ONOO}^{-}\right)$[64]. The reaction between $\mathrm{NO}^{-}$and $\mathrm{O}_{2}^{-}$- which results in $\mathrm{ONOO}^{-}$ production is three times faster than the reaction in which SOD catalyzes the dismutation of $\mathrm{O}_{2}{ }^{--}$to hydrogen peroxide (Fig. 2, B). The inactivation of G6PDH and GPx in group III could facilitate the accumulation of superoxide radical that interact with nitric oxide (Fig. 2, B). In addition, NO^in micromolar concentrations will reversibly inhibit CAT [65]. Although $\mathrm{ONOO}^{-}$is a strong oxidant, it reacts at a relatively slow rate with most biological molecules. With its reaction with carbon dioxide and other major reactions in cells taken into account, $\mathrm{ONOO}^{-}$can still diffuse quite far on a cellular scale. $\mathrm{ONOO}^{-}$is able to traverse cell membranes in part through anion channels [66].

Nitric oxide synthase-independent synthesis of NO` by molybdopterin nitrite reductases (including xanthine oxidoreductase, aldehyde oxidase, and sulfite oxidase) seems to be increased in high nitrite concentration; it could be speculated that nitrite administration increases $\mathrm{NO}^{\circ}$ formation and extracellular generated $\mathrm{ONOO}^{-}$gets into erythrocytes by crossing the membrane barrier into two pathways: the anion form through band 3 protein anion exchanger and the protonated form by passive diffusion through the lipid bilayer [67]. Tyrosine residues appear to be a major site of the reaction of peroxynitrite with many proteins. Soszynski et al. have demonstrated inactivation of ATPase activities after exposure to ONOO- [68]. Besides ATPase, RNS can lead to oxidation of amino acid residues and fragmentation of cytoskeleton protein, which disrupts viscoelastic properties of the erythrocyte membrane lipids (dotted line, Fig. 2, B) [69]. Thus the increased MDA, MetHb, and peroxynitrite indicate that multifactorial mechanisms might be involved in the toxicity of nitrates and nitrites which could be manifested by oxidative stress (Fig. 2). However, additional studies involving membrane protein and lipid analyses and measurements of lipophilic antioxidant levels in the erythrocytes subjected to nitrates and nitrites will clarify this point in the future.

Conclusion. It can be concluded from these observations that nitrate or nitrite leads to alterations in the erythrocytes antioxidant defense status mainly throughout NADPH and GSH-related enzymes. These results suggest the importance of G6PDH in the regulation of cellular function, that is, the ability of erythrocytes to cope up with oxidative stress induced by nitrates and nitrites. However, the different responses of the antioxidant enzymes indicated a complicated mechanism of oxidative stress regulation in the erythrocytes.

\section{Acknowledgments}

The present study was supported by the grant received by PIFI-SEP (No. 2012-10MSU0010C-07), and PROMEP (SEP-Mexico) No. 103.5/11/6827. We thank María A. Sánchez-Muñoz, Jorge A. SosaGutierrez and Eliab M. González-Olvera for their assistance.

Conflict of interest. The authors declare that there are no conflicts of interest. 


\section{НІТРАТИ І НІТРИТИ У ПИТНІЙ ВОДІ ВПЛИВАЮТЬ НА АНТИОКСИДАНТНІ ЕНЗИМИ В ЕРИТРОЦИТАХ ЩУРІВ}

E. Sierra-Campos ${ }^{1 凶}$, M. A. Valdez-

Solana ${ }^{1}$, M. I. Campos-Almazán ${ }^{1}$, C. Avitia-Domínguez², J. L. HernándezRivera $^{1}$, J. A. de Lira-Sánchez ${ }^{1}$, G. GarciaArenas $^{3}$, A. Téllez-Valencia ${ }^{2}$

${ }^{1}$ Faculty of Chemical Sciences, Campus Gómez Palacio, University Juarez of Durango

State, Gomez Palacio, Durango, Mexico; 凶e-mail: ericksier@gmail.com;

${ }^{2}$ Faculty of Medicine and Nutrition, Campus Durango, University Juarez of Durango State, Durango, Mexico;

${ }^{3}$ Faculty of Health Sciences, Campus Gómez Palacio, University Juarez of Durango State, Gomez Palacio, Durango, Mexico

У дослідженні оцінювали вплив короткострокового споживання питної води, що містить нітрати і нітрити, на антиоксидантну систему і мембрани еритроцитів щурів. Щури Wistar були випадковим чином розділені на три групи: тварини 1-ї групи (контрольної) пили тільки дистильовану воду ad libitum; у 2-й групі - воду, що містила нітрати в дозі 124 мг/кг; а в 3-й групі воду, що містила нітрити в дозі 150 мг/кг маси тіла протягом 7 днів. Наприкінці експерименту в щурів 3-ї групи спостерігали значне зниження активності глутатіонпероксидази (GPx), глюкозо-6-фосфатдегідрогенази (G6PDH) і каталази (САT); у щурів 2-ї групи активність GPх і САТ була значно знижена, тоді як активність глутатіонредуктази i рівень пероксинітриту були без змін. Рівень малондіальдегіду (MDA) був збільшений в обох групах порівняно 3 контрольною групою. Також показано, що рівень метгемоглобіну і осмотична крихкість змінювалися в щурів, які отримували воду 3 нітратами та нітритами, порівняно 3 контрольною групою. Зміни були найвираженішими в щурів 3-ї групи. Дійшли висновку, що нітрати i нітрити впливають на стан антиоксидантної системи в еритроцитах щурів, в основному, за рахунок зміни активності NADPH ензимів.

К л ю ч о в і сл о ва: нітрати, нітрити, окислювальний стрес, антиоксидантні ензими, метгемоглобін, еритроцити.

\section{НИТРАТЫ И НИТРИТЫ В ПИТЬЕВОЙ ВОДЕ ВЛИЯЮТ НА АНТИОКСИДАНТНЫЕ ЭНЗИМЫ В ЭРИТРОЦИТАХ КРЫС}

E. Sierra-Campos ${ }^{1 \bowtie}$, M. A. Valdez-

Solana ${ }^{1}$, M. I. Campos-Almazán ${ }^{1}$, C. Avitia-Domínguez², J. L. HernándezRivera $^{1}$, J. A. de Lira-Sánchez ${ }^{1}$, G. GarciaArenas $^{3}$, A. Téllez-Valencia ${ }^{2}$

${ }^{1}$ Faculty of Chemical Sciences, Campus Gómez Palacio, University Juarez of Durango State, Gomez Palacio, Durango, Mexico; $₫$ e-mail: ericksier@gmail.com;

${ }^{2}$ Faculty of Medicine and Nutrition, Campus Durango, University Juarez of Durango State, Durango, Mexico;

${ }^{3}$ Faculty of Health Sciences, Campus Gómez Palacio, University Juarez of Durango State, Gomez Palacio, Durango, Mexico

В настоящем исследовании оценивали влияние краткосрочного потребления питьевой воды, содержащей нитраты и нитриты, на антиоксидантную систему и мембраны эритроцитов крыс. Крысы Wistar были случайным образом разделены на три группы: животные 1-й группы (конрольной) пили только дистиллированную воду ad libitum; во 2-й группе - воду, содержащую нитраты в дозе 124 мг/кг; а в 3-й группе воду, содержащую нитриты в дозе 150 мг/кг массы тела в течение 7 дней. В конце эксперимента у крыс 3-й группы значительно снижалась активность глутатионпероксидазы (GPx), глюкозо6-фосфатдегидрогеназы (G6PDH) и каталазы (CAT); у крыс 2-й группы активность GPх и CAT была значительно снижена, в то же время активность глутатионредуктазы и уровень пероксинитрита были без изменений. Уровень малонового диальдегида (MDA) был увеличен в обоих группах по сравнению с контрольной группой. Также показано, что уровень метгемоглобина и осмотическая хрупкость изменялись у крыс, получавших воду с нитратами и нитритами, по сравнению с контрольной группой. Изменения были наиболее выражены у крыс 3-й группы. Сделан вывод, что нитраты и нитриты влияют на состояние антиоксидантной системы в эритроцитах крыс в основном за счет изменения активности NADPH энзимов.

К л ю че в ы е с ло ва: нитраты, нитриты, окислительный стресс, антиоксидантные энзимы, метгемоглобин, эритроциты. 


\section{References}

1. Fawell J, Nieuwenhuijsen MJ. Contaminants in drinking water: Environmental pollution and health. Br Med Bull. 2003; 68(1): 199-208.

2. Fan AM, Steinberg VE. Health implications of nitrate and nitrite in drinking water: an update on methemoglobinemia occurrence and reproductive and developmental toxicity. Regul Toxicol Pharmacol. 1996; 23(1 Pt 1): 35-43.

3. Medina-Morales M, Cano-Rios P. Contaminación por nitratos en agua, suelo y cultivos de la Comarca Lagunera. Revista Chapingo Serie Zonas Aridas. 2001; 2(1): 9-14.

4. Singhal S, Gupta R, Goyle A. Comparison of antioxidant efficacy of vitamin $\mathrm{E}$, vitamin $\mathrm{C}$, vitamin A and fruits in coronary heart disease: a controlled trial. J Assoc Physicians India. 2001; 49: 327-331.

5. Gladwin MT, Raat NJ, Shiva S, Dezfulian C, Hogg N, Kim-Shapiro DB, Patel RP. Nitrite as a vascular endocrine nitric oxide reservoir that contributes to hypoxic signaling, cytoprotection, and vasodilation. Am J Physiol Heart Circ Physiol. 2006; 291(5): H2026-H2035.

6. Sivilotti ML. Oxidant stress and haemolysis of the human erythrocyte. Toxicol Rev. 2004; 23(3): 169-188.

7. Kurata M, Suzuki M, Agar NS. Antioxidant systems and erythrocyte life-span in mammals. Comp Biochem Physiol B. 1993; 106(3): 477-487.

8. Vitak TY, Wasser SP, Nevo E, Sybirna NO. Enzymatic System of Antioxidant Protection of Erythrocytes in Diabetic Rats Treated with Medicinal Mushrooms Agaricus brasiliensis and Ganoderma lucidum (Agaricomycetes). Int J Med Mushrooms. 2017; 19(8): 697-708.

9. Mladenov M, Gokik M, Hadzi-Petrushev N, Gjorgoski I, Jankulovski N. The relationship between antioxidant enzymes and lipid peroxidation in senescent rat erythrocytes. Physiol Res. 2015; 64(6): 891-896.

10. Batina P, Fritsch P, de Saint Blanquat G, Mitjavila MT. In vitro kinetics of the oxidative reactivity of nitrate and nitrite in the rat erythrocyte. Food Addit Contam. 1990; 7(Suppl 1): S145-S149.

11. Ansari FA, Ali SN, Mahmood R. Sodium nitriteinduced oxidative stress causes membrane damage, protein oxidation, lipid peroxidation and alters major metabolic pathways in human erythrocytes. Toxicol In Vitro. 2015; 29(7): 18781886.

12. Shugaley IV, Lvov SN, Tselinsky IV, Baev VI. Effect of sodium nitrite poisoning on the activity of enzymes of anti-oxidant protection and peroxidation processes in mouse erythrocytes. Ukr Biokhim Zhurn. 1992; 64(2): 111-114. (In Russian).

13. Bouaziz-Ketata H, Salah GB, Mahjoubi A, Aidi Z, Kallel C, Kammoun H, Fakhfakh F, Zeghal N. Hyparrhenia hirta: A potential protective agent against hematotoxicity and genotoxicity of sodium nitrate in adult rats. Environ Toxicol. 2015; 30(11): 1275-1284.

14. May JM, Qu ZC, Xia L, Cobb CE. Nitrite uptake and metabolism and oxidant stress in human erythrocytes. Am J Physiol Cell Physiol. 2000; 279(6): C1946-C1954.

15. Bryan NS, Fernandez BO, Bauer SM, GarciaSaura MF, Milsom AB, Rassaf T, Maloney RE, Bharti A, Rodriguez J, Feelisch M. Nitrite is a signaling molecule and regulator of gene expression in mammalian tissues. Nat Chem Biol. 2005; 1(5): 290-297.

16. Bryan NS, Calvert JW, Elrod JW, Gundewar S, Ji SY, Lefer DJ. Dietary nitrite supplementation protects against myocardial ischemiareperfusion injury. Proc Natl Acad Sci USA. 2007; 104(48): 19144-19149.

17. Kleinbongard $P$, Dejam $A$, Lauer $T$, Jax $T$, Kerber S, Gharini P, Balzer J, Zotz RB, ScharfRE, Willers R, Schechter AN, Feelisch M, Kelm M. Plasma nitrite concentrations reflect the degree of endothelial dysfunction in humans. Free Radic Biol Med. 2006; 40(2): 295-302.

18. Lu N, Chen C, He Y, Tian R, Xiao Q, Peng YY. The dual effects of nitrite on hemoglobindependent redox reactions. Nitric Oxide. 2014; 40: 1-9.

19. Giles AR. Guidelines for the use of animals in biomedical research. Thromb Haemost. 1987; 58(4): 1078-1084.

20. Miller LC, Tainter ML. Estimation of the ED50 and Its Error by Means of Logarithmic-Probit Graph Paper. Exp Biol Med. 1944; 57(2): 261264.

21. Speijers GJA, Van Went GF, Van Apeldoorn ME, Montizaan GK, Janus JA, Canton JH, Van Gestel CAM, Van der Heijden CA, Heijna-Merkus E, Knaap AGAC, Luttik R, De Zwart D. Integrated criteria document nitrate: effects. Appendix to 
RIVM report nr. 758473007, National Institute of Public Health and Environmental Protection. Bilthoven, The Netherlands. 1987.

22. Modificación a la Norma Oficial Mexicana NOM127-SSA1-1994, Salud ambiental, agua para uso y consume humano. Límites permisibles de calidad y tratamiento a que debe someterse el agua para su potabilización. México. 2000.

23. Nagababu E, Rifkind JM. Heme degradation during autoxidation of oxyhemoglobin. Biochem Biophys Res Commun. 2000; 273(3): 839-845.

24. Hanson MS, Stephenson AH, Bowles EA, Sprague RS. Insulin inhibits human erythrocyte cAMP accumulation and ATP release: role of phosphodiesterase 3 and phosphoinositide 3-kinase. Exp Biol Med (Maywood). 2010; 235(2): 256-262.

25. Evelyn KA, Malloy HT. Microdetermination of oxyhemoglobin, methemoglobin, and sulfhemoglobin in a single sample blood. $J$ Biol Chem. 1938; 126: 655-662.

26. Sentürk UK, Gündüz F, Kuru O, Aktekin MR, Kipmen D, Yalçin O, Bor-Küçükatay $M$, Yeşilkaya A, Başkurt OK. Exercise-induced oxidative stress affects erythrocytes in sedentary rats but not exercise-trained rats. J Appl Physiol. 2001; 91(5): 1999-2004.

27. O'Dell BL, Browning JD, Reeves PG. Zinc deficiency increases the osmotic fragility of rat erythrocytes. J Nutr. 1987; 117(11): 1883-1889.

28. Huie RE, Padmaja S. The reaction of no with superoxide. Free Radic Res Commun. 1993; 18(4): 195-199.

29. Aebi H. Catalase in vitro. Methods Enzymol. 1984; 105: 121-126.

30. Staal GE, Visser J, Veeger C. Purification and properties of glutathione reductase of human erythrocytes. Biochim Biophys Acta. 1969; 185(1): 39-48.

31. Zinkham WH. The selective hemolytic action of drugs: clinical and mechanistic considerations. $J$ Pediatr. 1967; 70(2): 200-209.

32. Paglia DE, Valentine WN. Studies on the quantitative and qualitative characterization of erythrocyte glutathione peroxidase. J Lab Clin Med. 1967; 70(1): 158-169.

33. Bergmeyer HU. Methods of enzymatic analysis. New York: Academic Press. 1965.

34. Dodge JT, Mitchel C, Hanahan DJ. The preparation and chemical characteristics of hemoglobin-free ghosts of human erythrocytes. Arch Biochem Biophys. 1963; 100: 119-130.
35. Lowry OH, Rosebrough NJ, Farr LA, Randall RJ. Protein measurement with the folin phenol reagent. J Biol Chem. 1951; 193(1): 265-275.

36. Buege JA, Aust SD. Microsomal lipid peroxidation. Methods Enzymol. 1978; 52: 302310.

37. Joshi PK, Bose M, Harishi D. Haematological changes in the blood of Clarias batrachusn exposed to mercuric chloride. Ecotoxicol Enviro Monit. 2002; 12(2): 119-122.

38. Duncan C, Dougall H, Johnston P, Green S, Brogan R, Leifert C, Smith L, Golden M, Benjamin N. Chemical generation of nitric oxide in the mouth from the enterosalivary circulation of dietary nitrate. Nat Med. 1995; 1(6): 546-551.

39. Kumar D, Branch BG, Pattillo CB, Hood J, Thoma S, Simpson S, Illum S, Arora N, Chidlow JH Jr, Langston W, Teng X, Lefer DJ, Patel RP, Kevil CG. Chronic sodium nitrite therapy augments ischemia-induced angiogenesis and arteriogenesis. Proc Natl Acad Sci USA. 2008; 105(21): 7540-7545.

40. Basic Information about Nitrite (Measured as Nitrogen) in Drinking Water. [Electronic resource]. Regime of access: http://www. fredericktownelabs.com/basic-informationabout-nitrite-measured-as-nitrogen-indrinking-water/.

41. Kolanjiappan K, Manoharan S, Kayalvizhi M. Measurement of erythrocyte lipids, lipid peroxidation, antioxidants and osmotic fragility in cervical cancer patients. Clin Chim Acta. 2002; 326(1-2): 143-149.

42. Adenkola AY, Ayo JO. Effect of road transportation on erythrocyte osmotic fragility of pigs administered ascorbic acid during the harmattan season in Zaria, Nigeria. J Cell Anim Biol. 2009; 3(1): 4-8.

43. Brzezińska-Slebodzińska E. Erythrocyte osmotic fragility test as the measure of defence against free radicals in rabbits of different age. Acta Vet Hung. 2001; 49(4): 413-419.

44. Misra HP, Fridovich I. The generation of superoxide radical during the autoxidation of hemoglobin. J Biol Chem. 1972; 247(21): 69606962.

45. Jain SK, Hochstein P. Polymerization of membrane components in aging red blood cells. Biochem Biophys Res Commun. 1980; 92(1): 247-254.

46. Hochstein P, Jain SK. Association of lipid peroxidation and polymerization of membrane 
proteins with erythrocyte aging. Fed Proc. 1981; 40(2): 183-188.

47. Giulivi C, Hochstein P, Davies KJ. Hydrogen peroxide production by red blood cells. Free Radic Biol Med. 1994; 16(1): 123-129.

48. Sadrzadeh SM, Graf E, Panter SS, Hallaway PE, Eaton JW. Hemoglobin. A biologic fenton reagent. J Biol Chem. 1984; 259(23): 1435414356.

49. Borković SS, Saponjić JS, Pavlović SZ, Blagojević DP, Milosević SM, Kovacević TB, Radojicić RM, Spasić MB, Zikić RV, Saicić ZS. The activity of antioxidant defence enzymes in the mussel Mytilus galloprovincialis from the Adriatic Sea. Comp Biochem Physiol C Toxicol Pharmacol. 2005; 141(4): 366-374.

50. Shimizu N, Kobayashi K, Hayashi K. The reaction of superoxide radical with catalase. Mechanism of the inhibition of catalase by superoxide radical. J Biol Chem. 1984; 259(7): 4414-4418.

51. Ansari FA, Ali SN, Mahmood R. Crocin protects human erythrocytes from nitrite-induced methemoglobin formation and oxidative damage. Cell Biol Int. 2016; 40(12): 1320-1331.

52. Rober D, Mark L, Mitchell L. Investigation of the hereditary haemolytic anaemia: membrane and enzyme abnormalities. Churchill Livingstone, New York. 2001.

53. Devasena T, Lalitha S, Padma K. Lipid peroxidation, osmotic fragility and antioxidant status in children with acute post-streptococcal glomerulonephritis. Clin Chim Acta. 2001; 308(1-2): 155-161.

54. Krishnamoorthy P, Sangeetha M. Hepatoprotective effect of vitamin $\mathrm{C}$ on sodium nitriteinduced lipid peroxidation in albino rats. Indian J Biochem Biophys. 2008; 45: 206-208.

55. Marks PA. Enzymes of the pentose phosphate pathway. Methods Med Res. 1961; 9: 24-35.

56. Sandhir R, Parwani S, Kiran R. Effect of fenvalerate exposure on erythrocyte antioxidant status in protein malnourished rats. Toxicol Environ Chem. 2002; 83(1-4): 99-106.

57. Carlström M, Persson AE, Larsson E, Hezel M, Scheffer PG, Teerlink T, Weitzberg E, Lundberg JO. Dietary nitrate attenuates oxidative stress, prevents cardiac and renal injuries, and reduces blood pressure in saltinduced hypertension. Cardiovasc Res. 2011; 89(3): 574-585.
58.ZuckerbraunBS, Shiva S, Ifedigbo E, MathierMA, Mollen KP, Rao J, Bauer PM, Choi JJ, Curtis E, Choi AM, Gladwin MT. Nitrite potently inhibits hypoxic and inflammatory pulmonary arterial hypertension and smooth muscle proliferation via xanthine oxidoreductase-dependent nitric oxide generation. Circulation. 2010; 121(1): 98109.

59. Yang T, Peleli M, Zollbrecht C, Giulietti A, Terrando N, Lundberg JO, Weitzberg E, Carlström M. Inorganic nitrite attenuates NADPH oxidase-derived superoxide generation in activated macrophages via a nitric oxidedependent mechanism. Free Radic Biol Med. 2015; 83: 159-166.

60. Lundberg JO, Weitzberg E, Gladwin MT. The nitrate-nitrite-nitric oxide pathway in physiology and therapeutics. Nat Rev Drug Discov. 2008; 7(2): 156-167.

61. Chen B, Keshive M, Deen WM. Diffusion and reaction of nitric oxide in suspension cell cultures. Biophys J. 1998; 75(2): 745-754.

62. MacMicking J, Xie QW, Nathan C. Nitric oxide and macrophage function. Annu Rev Immunol. 1997; 15(1): 323-350.

63. Dedon PC, Tannenbaum SR. Reactive nitrogen species in the chemical biology of inflammation. Arch Biochem Biophys. 2004; 423(1): 12-22.

64. Shafirovich V, Cadet J, Gasparutto D, Dourandin A, Geacintov NE. Nitrogen dioxide as an oxidizing agent of 8-oxo-7,8-dihydro-2'deoxyguanosine but not of 2'-deoxyguanosine. Chem Res Toxicol. 2001; 14(2): 233-241.

65. Brunelli L, Yermilov V, Beckman JS. Modulation of catalase peroxidatic and catalatic activity by nitric oxide. Free Radic Biol Med. 2001; 30(7): 709-714.

66. Denicola A, Souza JM, Radi R. Diffusion of peroxynitrite across erythrocyte membranes. Proc Natl Acad Sci USA. 1998; 95(7): 3566-3571.

67. Marla SS, Lee J, Groves JT. Peroxynitrite rapidly permeates phospholipid membranes. Proc Natl Acad Sci USA. 1997; 94(26): 14243-14248.

68. Soszyński M, Bartosz G. Effect of peroxynitrite on erythrocytes. Biochim Biophys Acta. 1996; 1291(2): 107-114.

69. Pandey KB, Rizvi SI. Biomarkers of oxidative stress in red blood cells. Biomed Pap Med Fac Univ Palacky Olomouc Czech Repub. 2011; 155(2): 131-136.

Received 15.03.2018 